\title{
LINGUISTIC IMAGE OF RUSSIA IN AMERICAN PRINTED MEDIA (CASE-STUDY OF HEADLINE COMPLEXES) ${ }^{1}$
}

\author{
Natalya V. Yudina \\ Financial University under the Government of the Russian Federation, Moscow, Russia
}

Oksana A. Seliverstova

Vladimir State University, Vladimir, Russia

\begin{abstract}
The paper presents a linguistic image of Russia as shown by the US printed media. The study was conducted with two interrelated and complementary methods: that of describing associative semantic field and that of investigating qualia-structure of the concept, based on the generative lexicon theory by J. Pusteiovsky. Both methods resulted in building a layered concept structure with a core, a transition zone and periphery. For the purpose of the study, a corpus containing 3636 collocates with "Russia" as the key word was derived from headline complexes of US printed media: The Washington post and the New York Times. The analysis of the structure and composition of the associative semantic field has enabled the author to confirm significant influence of extralinguistic factors on the construction of linguistic images. The study involved processing previously made corpus with corpus management software to provide numeric data on lexemes frequency. Associative semantic field revealed the newsworthy events that put Russia in focus in headlines complexes: President Election of 2016 and investigation of Russia's supposed involvement, intelligence services and related causes celebre, sanctions, armed conflicts, coronavirus spread and oil prices fluctuations. Qualia-structure semantic analysis brought forth the main frames in the Russia concept structure: Russia as an aggressive power, Russia as a counterpart, Russia as a partner, and Russia as a destination.

Key words: linguistic image, concept "Russia", concept structure, qualia-structure of the concept, headline complex, associative semantic field.

Citation. Yudina N.V., Seliverstova O.A. Linguistic Image of Russia in American Printed Media (Case-Study of Headline Complexes). Vestnik Volgogradskogo gosudarstvennogo universiteta. Seriya 2. Yazykoznanie [Science Journal of Volgograd State University. Linguistics], 2020, vol. 19, no. 6, pp. 169-179. (in Russian). DOI: https:// doi.org/10.15688/jvolsu2.2020.6.13
\end{abstract}

\section{ЛИНГВИСТИЧЕСКИЙ ОБРАЗ РОССИИ В СРЕДСТВАХ МАССОВОЙ ИНФОРМАЦИИ США (НА МАТЕРИАЛЕ ЗАГОЛОВОЧНЫХ КОМПЛЕКСОВ) ${ }^{1}$}

\author{
Наталья Владимировна Юдина \\ Финансовый университет при Правительстве Российской Федерации, г. Москва, Россия \\ Оксана Александровна Селиверстова \\ Владимирский государственный университет им. А.Г. и Н.Г. Столетовых, г. Владимир, Россия
}

Аннотация. Статья посвящена описанию лингвистического образа современной России на материале заголовочных комплексов американских печатных средств массовой информации. Исследование проводилось 
с помощью метода конструирования ассоциативно-семантического поля на основе данных о частотности лексем ближайшего контекста, полученных при обработке собранного корпуса программой-менеджером корпусов, а также метода описания смысловой (qualia) структуры с опорой на теорию генеративного лексикона Дж. Пустейовского. В результате использования каждого из указанных методов была построена структура концепта «Россия / Russia», состоящая из ядра, околоядерной зоны, ближайшей и дальней периферии. Анализ структуры и состава ассоциативно-семантического поля позволил подтвердить большое влияние экстралингвистических факторов на конструирование лингвистических образов. Установлено, что к наиболее значимым информационным поводам, в связи с которыми Россия упоминалась в заголовках американских СМИ, относятся выборы президента США 2016 г. и расследование о возможном вмешательстве в них России, деятельность разведслужб, санкции, вооруженные конфликты, распространение коронавируса и связанное с ним падение цен на нефть. В смысловой структуре концепта ядром является фрейм «Россия агрессор», околоядерную зону формирует фрейм «Россия - участник отношений», периферийную - фреймы «Россия - партнер» и «Россия - географический объект».

Ключевые слова: лингвистический портрет, концепт «Россия», структура концепта, смысловая структура концепта, заголовочный комплекс, ассоциативно-семантическое поле.

Цитирование. Юдина Н. В., Селиверстова О. А. Лингвистический образ России в средствах массовой информации США (на материале заголовочных комплексов) // Вестник Волгоградского государственного университета. Серия 2, Языкознание. -2020. - Т. 19, № 6. -C. 169-179. - DOI: https://doi.org/10.15688/jvolsu2.2020.6.13

\section{Введение}

Описание лингвистического образа государств и отдельных национальных, социальных, профессиональных и иных групп является в настоящее время одним из наиболее продуктивных и перспективных направлений исследований, находящихся на стыке лингвистического и экстралингвистического знания. Вероятно, указанный интерес обусловлен поиском неких основополагающих компонентов, составляющих образ государств и национальностей в коллективном сознании. В этой связи конструированию образов наиболее сильных, неординарных и конкурентоспособных государств посвящено большое количество работ отечественных и зарубежных исследователей.

Лингвистический портрет России неоднократно становился объектом пристального внимания специалистов в сфере широкого гуманитарного научного знания. Наиболее плодотворными, на наш взгляд, являются работы, выполненные в лингвокультурологическом и лингвокогнитивном аспектах. Особую группу составляют исследования образа России в дискурсе СМИ, представленные на основе анализа британских [Боева-Омелечко, Постерняк, 2015; Красильникова, 2007], американских [Орлова, 2011; 2015], немецких [Осипова, Михина, Позднякова, 2016; Точилина., 2013] средств массовой информации. Большое количество исследований в этом на- правлении свидетельствует о восприятии образа России как совокупности смыслов, целенаправленно формируемых разными способами, в том числе и посредством манипулятивных стратегий в СМИ. В связи с этим справедливой представляется позиция Л.Н. Ребриной и Н.Л. Шамне, указавших при характеристике коммуникативного взаимодействия средств массовой информации с аудиторией на то, что данное взаимодействие «базируется на субъект-объектном отношении отправителя и получателя сообщения, апелляции к психологической или логической сферам последнего, на “упаковке” смысла в содержание до коммуникативного акта и инициации присвоения данного смысла адресатом как собственного» [Ребрина, Шамне, 2017, с. 158]. Таким образом, формируемые СМИ представления закладывают основу общественного мнения.

Очевидно, что особое значение в текстах печатных средств массовой информации имеет заголовок, поскольку он «является первым сигналом, побуждающим нас читать материал или отложить газету в сторону. Исследования психологов показывают, что около 80 \% читателей уделяют внимание только заголовкам» [Лазарева, 1989, с. 3]. По мнению К.В. Прохоровой, в газетной публицистике последних лет отмечается тенденция использования вместо отдельного заголовка заголовочного комплекса, понимаемого как «структурно-семантическое объедине- 
ние элементов текста, не только предваряющих его, но и органически связанных, содержательно и концептуально, с основным массивом конкретного текста» [Прохорова, 2012, c. 239]. В структуру заголовочного комплекса входит название тематической полосы, шапка, рубрика, заголовок, подзаголовок, лид, а также внутренние заголовки. Емкость заголовочных комплексов, сочетание экспрессивности и публицистичности обусловили внимание к ним как к материалу для исследований в сфере психологии, журналистики, лингвистики, в том числе и для лингвокогнитивного моделирования. Примером такого исследования является работа А.И. Белоусовой, направленная на «конструирование фреймовой модели как инструмента для репрезентации концепта-онима “РОССИЯ”» [Белоусова, 2010, c. 60].

Статья посвящена исследованию образа России через заголовочные комплексы, извлеченные из американских средств массовой информации 2017-2020 годов. Цель работы состоит в изучении образа России посредством концептуального моделирования на основе количественных данных. В качестве объекта исследования выступает концепт «Россия / Russia» и его репрезентация в дискурсе американских средств массовой информации, предмет исследования составляет ассоциативно-семантическое поле, а также структура концепта «Россия / Russia». Актуальность представленного исследования обусловлена как новейшим языковым материалом, так и недостаточной изученностью роли заголовочных комплексов в формировании метафорических контекстов образа России в сознании современной языковой личности.

\section{Материал и методы}

Материалом исследования являются заголовочные комплексы представленных в электронном формате американских печатных изданий «The New York Times» и «The Washington Post». Выбор указанных СМИ обусловлен их высоким тиражом: данные издания по состоянию на январь 2020 г. входят в США в первую десятку, а в 2017-2019 гг. занимали первое и второе место соответ- ственно (www.agilitypr.com). Методом сплошной выборки из указанных СМИ, вышедших за период с октября 2017 г. по апрель 2020 г., были отобраны заголовки, содержащие лемму Russia, на основе которых сформирован электронный корпус, состоящий из 3636 словоупотреблений. Он обработан при помощи программы AntConc для сбора количественных данных о частотности лексем, их сочетаемости и контекстуальном употреблении.

В исследовании использованы два взаимодополняющих метода: метод построения ассоциативно-семантического поля и метод анализа смысловой структуры концепта. Вслед за Е.С. Кубряковой мы понимаем «концепт» как термин, служащий объяснению ментальных или психических ресурсов нашего сознания и той информационной структуры, которая отражает знание и опыт человека; как оперативную содержательную единицу памяти, ментального лексикона, концептуальной системы и языка мозга (lingua mentalis), всей картины мира, отраженной в человеческой психике, квант знания [Кубрякова, 1996, с. 90]. Выбранные методы основаны на корпусном подходе к материалу исследования, который позволяет получить количественные данные о частотности лексем, словоупотреблениях и коллокатах.

Первый из методов связан с термином «ассоциативно-семантическое поле», толкуемым как проекция концепта / образа на индивидуальный лексикон, включающий все лексические единицы, составляющие ближайший контекст имени концепта / образа [Чурилина, 2001, с. 103]. Ассоциативно-семантическое поле представляет собой «сложную иерархически организованную структурную модель семантических микрополей, отображающую коммуникативные свойства слова и обусловленную коммуникативными установками автора» [Инь Бинь, 2014, с. 311]. Оно моделируется при помощи семантических микрополей с иерархической структурой [Инь Бинь, 2014, c. 312], которая включает в себя такие структурные элементы, как ядро, околоядерная зона и периферия. Данная модель отображает коммуникативные свойства слова и в значительной степени определяет присущие автору коммуникативные установки [Инь Бинь, 2014]. Вместе с тем «ассоциативный потенциал» 
лексического значения включает всю известную человеку информацию, касающуюся денотата, возникающие с ним разного рода ассоциации, фон, на котором функционируют языковые единицы. Все это входит в ментальный лексикон человека, поэтому ассоциативносемантическое поле может выступать в роли адекватного языкового воплощения изучаемого концепта / образа.

В основе второго из используемых методов исследования находится теория генеративного лексикона Дж. Пустейовского, основанная на идее о четырех типах структур в составе концепта: 1) смысловая структура (qualiastructure); 2) структура событий (eventstructure); 3) структура лексического наследования; 4) аргументная структура (argumentstructure) [Методы когнитивного анализа..., 2015]. Среди перечисленных структур особо значима для нас смысловая структура, под которой понимается комбинация из четырех полей: конститутивного, формального, целевого (телического) и агентивного. По Дж. Пустейовскому, конститутивное поле определяет, каким образом взаимосвязаны объект и его составные части, формальное поле характеризует категориальную принадлежность объекта, целевое включает информацию о назначении объекта, агентивное заключает в себе информацию о том, откуда и каким образом возник изучаемый объект [Pustejovsky, 1995, p. 76]. Для нашего исследования особо ценно целевое поле, в значительной степени формируемое действиями, выполняемыми референтом, и действиями, выполняемыми над ним. Именно описание целевого поля позволяет эксплицировать оценочное восприятие образа России в ходе фреймового анализа, в котором фрейм являет собой «опосредованную структуру, соединяющую область когнитивного тезауруса с языковым» [Никонова, 2007, с. 230]. Таким образом, фреймовый анализ используется для описания смысловой структуры, которая включает в себя концептуальный уровень, представленный фреймами, и языковой уровень, представленный семантическими полями.

Метод анализа смысловой структуры эффективно используется для моделирования процессов возникновения значений полисеман- тов, однако в сочетании с возможностями корпусного подхода он также может успешно применяться для концептуальных исследований, позволяя моделировать структуру концепта на основе количественных данных, облегчающих выделение ядра, околоядерной зоны и периферии.

\section{Результаты и обсуждение}

Для построения ассоциативно-семантического поля концепта «Россия» в интересующем нас дискурсе при помощи конкордансера из созданного нами корпуса (3 636 словоупотреблений, извлеченных из заголовочных комплексов американских изданий «The New York Times» и «The Washington Post») были отобраны наиболее частотные лексемы-коллокаты леммы Russia:

\begin{tabular}{|c|c|l|}
\hline $\begin{array}{c}\text { № } \\
\text { ח/п }\end{array}$ & $\begin{array}{c}\text { Количество } \\
\text { словоупотреблений }\end{array}$ & \multicolumn{1}{|c|}{ Лексическая единица } \\
\hline 1 & 590 & president / presidential \\
\hline 2 & 309 & election / elections / electoral \\
\hline 3 & 285 & investigation / investigators \\
\hline 4 & 196 & attack \\
\hline 5 & 194 & campaign \\
\hline 6 & 172 & oil \\
\hline 7 & 167 & spy / spies \\
\hline 8 & 153 & virus / coronavirus \\
\hline 9 & 149 & official / officials \\
\hline 10 & 138 & sanctions / sanctioned \\
\hline 11 & 137 & intelligence \\
\hline 12 & 122 & agent \\
\hline 13 & 120 & inquiry \\
\hline
\end{tabular}

К ядру ассоциативно-семантического поля концепта «Россия / Russia» в дискурсе американских СМИ относятся лексемы president / presidential. Указанные в таблице данные о количестве словоупотреблений свидетельствуют о том, что в центре внимания современных американских изданий находятся события, связанные с президентом (president / presidential), а также отношения между президентами двух стран. Это наблюдение подтверждается и значительным количеством словоупотреблений таких имен собственных, как Trump (942) и Putin (339). К околоядерной зоне мы считаем возможным отнести слова election / electoral, investigation / investigators, которые обозначают конкретные события, где главную роль играет президент: президентские выборы (election) и расследо- 
вание этого процесса (investigation). Периферию поля образуют лексические единицы attack, campaign, spy, official / officials, virus / coronavirus, sanctions / sanctioned, intelligence, inquiry, появление которых среди наиболее частотных единиц обусловлено преимущественно экстралингвистическими факторами, а именно: расследованием, связанным с предвыборной кампанией (campaign) и итогами выборов; интересом к деятельности международных организаций, в частности разведывательных организаций (intelligence). Не менее актуальны меры воздействия, активно применяемые в настоящее время в международной политике (sanctions), и агрессивные действия во внешней политике стран (attack), связанные с упоминаниями лиц, принимающих участие во внешней политике от лица государств, например официальных лиц (officials) и сотрудников разведывательных служб (spy).

В целом лексические единицы, составляющие ассоциативно-семантическое поле кон- цепта «Россия / Russia» в американских СМИ, можно разделить на следующие категории:

a) должностные лица или государственные службы, включая разведку (president, spy, intelligence), - 894 употребления;

б) меры восстановления правопорядка, а также лица, осуществляющие такие меры или попадающие под их действие (investigation / investigators, inquiry, sanctions / sanctioned), 543 употребления;

в) политические мероприятия (election / electoral, campaign) - 503 употребления;

г) агрессия как отдельная категория (attack) - 196 употреблений.

Приведенные показатели графически представлены на диаграмме (см. рисунок).

Данные диаграммы свидетельствуют об информационных поводах, которые стали основаниями для упоминания России в новейших американских средствах массовой информации. При более детальном анализе корпуса можно говорить об устойчивой связи между определенными частотными лексемами, группами

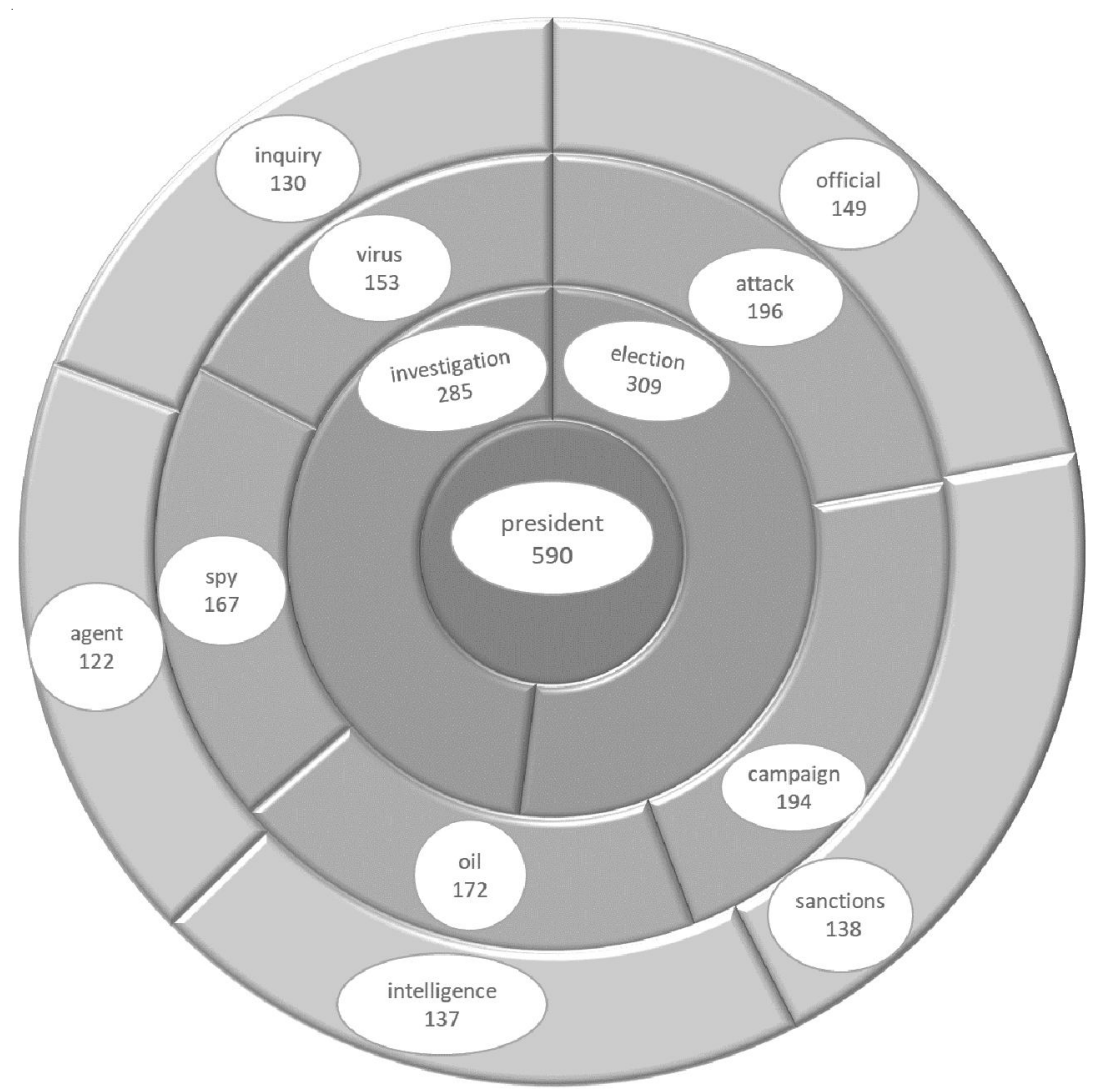

Ассоциативно-семантическое поле концепта «Россия / Russia»

Associative semantic field of the concept Russia 


\section{МАТЕРИАЛЫ И СООБЩЕНИЯ}

лексем и периодами наиболее активного обсуждения в СМИ событий и тем международной политической повестки. Так, к наиболее значимым информационным поводам, вызвавшим интерес у средств массовой информации США, можно отнести следующие позиции:

1) предположение о вмешательстве России в президентские выборы в Америке в 2016 г., в результате которых пост президента США занял Дональд Трамп, и проводимое по этому поводу расследование. Примечательно, что частотное распределение лексем, тематически сопряженных с этими событиями, после определенного спада в 2018-2019 гг. стало возрастать в 2020 г. в преддверии новых президентских выборов в США и в силу опасений относительно возможного влияния России на их результаты;

2) деятельность разведывательных служб и связанные с ней громкие дела. Об этом свидетельствует наличие в зоне периферии лексем agent, spy, intelligence;

3) вооруженные конфликты, в которых Россия выступает в качестве посредников урегулирования, например в Сирии;

4) меры воздействия на Россию по ряду вопросов. Однако в течение первых месяцев 2020 г. эта тема вытесняется информационными поводами, связанными с распространением коронавируса и последовавшим за ним падением цен на нефть. В этой связи существенно выросла частотность лексем virus и $o i l$, оказавшихся в околоядерной зоне.

Для моделирования концепта «Россия / Russia» посредством фреймового анализа из собранного корпуса с помощью программы для работы с корпусом AntConc были отобраны глаголы, обозначающие действия, при которых Россия выступает объектом и субъектом, а также атрибутивные распространители (чаще это одиночные имена прилагательные), используемые по отношению к России. На основе анализа новейшего языкового материала представляется целесообразным выделить в структуре концепта «Россия» четыре фрейма: «Россия - агрессор», «Россия - участник отношений», «Россия - партнер», «Россия - географический объект», расположив их в зависимости от частотности появления в средствах массовой информации.
Фрейм «Россия - агрессор» связан с использованием конструкций со значением действия с преимущественно пейоративной коннотацией, обозначающих попытки манипулировать, реагировать на обвинения, протесты и препятствия, а также на агрессивное и конфликтное поведение. В структуре целевого поля можно выделить следующие семантические группы (количество словоупотреблений приведено в скобках):

- наказывать, применять санкции (46): ban from the Olympics; ban from the Winter Games; ban from the 2018 Winter Games; bar entirely; be punitive toward; dig into; hit with sanctions; ignore; keep out of international sport; play up the administration's sanctions against; take action against; take to court over downing of jet over Ukraine, etc.;

- представлять опасность, манипулировать (36): be under watchdog's gaze; begin efforts; have ability to destroy America; not to stop cyberattacks on smb. sponsor terrorism; stage one's own civil war; suggest sabotage; teach Paul Manafort all its dirty tricks; target smb's personal servers; use its oil giant as a foreign policy tool, etc.;

- выдвигать обвинения, реагировать на обвинения (35): call hacking claims absurd; dismiss claims as 'fantasies'; dismiss suspected spy actions as routine Dutch trip; get caught, etc.;

- вмешиваться (28): attack election system; hack voting systems; help tip the election; meddle (in the election; in Brexit; in Italy's election; in the Olympics); throw the election to Trump; use mainstream media to manipulate American voters, etc.;

- наращивать военную мощь, применять силу (25): conduct exercise of nuclear forces; sign a new military accord; expand arsenal; develop nuclear arms; be poised to add a new hypersonic nuclear-capable glider to its arsenal; test missiles; show off new missile; stockpile lethal nerve agent; fire on vessels; open fire; strike back, etc;

- обманывать, обходить запреты и правила, скрывать что-то (19): cheat; fool; lie; not to play by international rules; slam sanctions; try to cheat its way to glory; use a side door to do smth, etc.

Итак, средства массовой информации США (2017-2020 гг.) конструируют образ 
России как государства, которое ведет недобросовестную политику, нарушая правила и договоренности, активно пытается манипулировать политикой других стран и регионов, отрицая при этом свою причастность, а также представляет собой опасность вследствие значительного военного потенциала и готовности использовать жесткую силу и вести военные действия, в связи с чем подвергается обвинениям и санкциям. Этот вывод в значительной мере подтверждается данными анализа конститутивно-инферентного субфрейма на основе анализа прилагательных. Среди прилагательных, имеющих коннотативную окраску, преобладают прилагательные с яркой негативной коннотацией, характеризующие поведение страны как участника международных отношений как неприемлемое (noncompliant, complicit) либо как опасное и агрессивное (reckless, furious), из прилагательных с мелиоративной коннотацией зафиксировано лишь одно (holy).

Фрейм «Россия - участник отношений», вербализуемый через целевое поле, включает в себя все действия с невыраженной (нейтральной) коннотативной окраской, где Россия выступает как объектом, так и субъектом международных отношений. Среди наиболее частотных можно выделить следующие действия России и действия по отношению к ней:

- взаимодействие (50): agree; allow smb to do smth; back; call; call on smb to do smth; claim; confirm smth positive; discuss smth; explain; find agreement on; find common foe; flood social media with theories; get smb into smth; point out; play nice with foreigners; promise to end smth; regard a statement as dangerous; respond to rumors; tell smb smth / of smth; say; send a message to opponents of smb; signal; warn smb not to do smth, etc;

- экономические операции (48): agree to lift/cut oil output; buy ads; cut / boost oil production; get a strong return on its investment; increase output spend money; offset reduction in Iranian exports; see common cause in tamping down oil prices; weigh production cuts to prop up oil production, etc;

- оценочное отночение (30): avoid condemning for its election meddling; be critical of; be obsessed with; care about; expect to do smth; focus on; have something bad to say about; love; make inaccurate statements about; make a hockey favourite; mock dealings with; misunderstand; rule for; shift course on; turn to; tweet about; understand, etc;

- описание планов и намерений (13): bet on its people; consider response to U.S. nuclear stance; go after; focus on; move up next launch; outline plans; plan smb's future; push further into Africa; set to resume smth; target weigh, etc;

- созидание, проявление инициативbl (11): build; create; establish; introduce; invite Taliban to Moscow; overcome differences; research; roll out a plan; shape narrative of summit; stage; take central stage at summits, etc;

- поддержкка, попытки расположить к себе (8): favor Trump; groom smb; push for the democrats; root for Trump; seek release of smb; stick up for smb; want Trump to win; woo South Africa's white farmers, etc;

- указание на трудную ситуацию (7): be lost from the start; face sports crisis; face crisis; fall; find unlikely ally; take economic hit from sanctions; take further step toward major schism in Orthodox church, etc;

Соотношение компонентов в составе целевого поля фрейма «Россия - участник отношений» существенно изменилось с начала 2020 года. Так, нарастающий в связи с распространением коронавируса экономический кризис и резкое падение цен на нефть находят отражение в речи: в СМИ увеличивается количество глагольных сочетаний семантической группы «экономические операции», которая по квантитативным показателям приблизилась к глаголам общей группы «взаимодействие», что с учетом короткого времени в 3месяца представляется существенным изменением в структуре поля.

Фрейм «Россия - партнер», вербализованный через целевое поле, включает в себя действия с преимущественно положительной коннотацией, обозначающие помощь, примирение, сотрудничество и совместную работу:

- сотрудничество (36): be a safe and reliable provider; buy smth; sign treaty with; deliver S-300 air defenses to Syria; ease debt 


\section{МАТЕРИАЛЫ И СООБЩЕНИЯ}

burden on smb; extend U.S. space partnership; glimpse common ground with; help; live up promises; modernize Syria's missile arsenal; offer help; reach a deal; seek a meeting with; sign a deal; strike a private deal; urge closer ties with, etc;

- примирение (15): agree to set up a demilitarized zone to avert smth; be allowed in G-7; be reinstated to G-7 exit East Ukraine; halt development of new missiles; find agreement on smth; plan peace talks; push to end war; respond to airstrikes in Syria with harsh words but no fire promote a truce; run low on Soviet tanks; scrap chemical weapons; seek peace with Japan; settle decades-long dispute; stop cyber attacks on West, etc;

- участие в мировых спортивных событиях (13): advance to the quarterfinals; be not expected to beat smb; beat Saudi Arabia; cheer; get athletes cleared; open the 2018 World Cup with a victory; score an Olympic own goal; send athletes to Winter Olympics; set the World Cup table win hockey gold; welcome the world; win, etc;

- восстановление в правах / положении (9): bring back to world sport; clear of charges; lift a ban on; lift sanctions on; readmit; reinstate; take off the list of noncompliant countries; want back, etc.

Обращает на себя внимание тот факт, что глаголы, объединенные семой «сотрудничество», характеризуют сотрудничество в различных сфеpax. Наиболее частотными являются сфера экономики (be a safe and reliable provider; buy smth; ease debt burden on smb; reach a deal; sign a deal; strike a private deal; sign a treaty with) и оборонная промышленность (deliver S-300 air defenses to Syria; complete the delivery of S-300 air defense systems to Syria). При этом, анализируя количественные показатели, можем заметить, что данный фрейм выражен в гораздо меньшей степени, чем описанные выше фреймы.

Фрейм «Россия - географический объект» реализуется в конститутивно-инферентном и целевом полях. Первое представлено нейтральными прилагательными без коннотативной окраски, характеризующими географическое положение (southern, northern, central) и инфраструктуру (urban, rural). Целевое поле рассматриваемого фрейма объединяет следующие действия:
- прибытие (5): fly from; head to; invade; travel to; visit;

- отъезд (2): flee from; fly from;

- непростое для посещения место (2): cost smb a spot; prove a challenging destination;

- возможная радиоактивная опасnocmb (1): be named as likely source of Europe radioactivity spike.

Анализ показывает, что действия, реализующие фрейм «Россия - географический объект», как правило, выражены глаголами движения. Это может быть добровольное (fly from; head to; invade; travel to; visit) или вынужденное (flee to; flee from) передвижение в страну или из нее. Данный фрейм представлен наименьшим количеством лексических единиц (15) по сравнению с другими описанными выше фреймами.

\section{Выводы}

Лингвистический образ России, конструируемый в новейших средствах массовой информации США, является динамичным. Важный фактор его создания - выбор информационных поводов, в связи с которыми название государства используется в заголовках и заголовочных комплексах средств массовой информации США. При этом преобладают темы, в рамках которых действия России представлены как опасные, имеющие манипулятивный характер и реализующие фрейм «Россия - агрессор». Принимая во внимание частотность лексем с пейоративной коннотацией, отметим постепенный рост употребления нейтральных лексем, формирующих образ России как участника международных отношений.

Продолжением исследования станет ассоциативный эксперимент с опросом респондентов из США для установления соотношения между формируемым и сформированным образом России, определяющим отношение к ней граждан США, и описания степени влияния СМИ на сознание целевой аудитории, результативности и потенциала использования приемов и тактик при конструировании лингвистического образа России в новейших средствах массовой информации США. 


\section{ПРИМЕЧАНИЕ}

${ }^{1}$ Статья подготовлена по результатам исследований, выполненных за счет бюджетных средств по государственному заданию ФГОБУ ВО «Финансовый университет при Правительстве Российской Федерации».

The paper presents results of the research carried out by Financial University under the Government of the Russian Federation funded by the government and in accordance with its task.

\section{СПИСОК ЛИТЕРАТУРЫ}

Белоусова А. И., 2010. Фреймовая модель как способ структурирования ономастического концепта «Россия» // Вестник Череповецкого государственного университета. № 3. С. 59-63.

Боева-Омелечко Н. Б., Постерняк К. П., 2015. Репрезентация ассоциативной составляющей концепта Россия в современных британских СМИ // Когнитивные исследования языка. № 21. С. 310-312.

Инь Бинь, 2014. Ассоциативно-семантическое поле концепта «корова» в современном русском языке// Известия высших учебных заведений. Серия «Гуманитарные науки». Т. 5, № 4. C. 311-314.

Красильникова Н. А., 2007. «Заложники русского медведя»: метафорическое представление современной России в британских и американских СМИ // Вопросы когнитивной лингвистики. № 1 (10). С. 42-49.

Кубрякова Е. С., 1996. Концепт // Краткий словарь когнитивных терминов / под общ. ред. Е. С. Кубряковой. М. : Изд-во Моск. гос. ун-та. С. 90-92.

Лазарева Э. А., 1989. Заголовок в газете. Свердловск : Изд-во Урал. ун-та. 96 с.

Методы когнитивного анализа семантики слова: компьютерно-корпусный подход, 2015 / В. И. Заботкина [и др.]; под общ. ред. В. И. Заботкиной. М. : Яз. слав. культуры. 344 с.

Никонова Ж. В., 2007. Фреймовый анализ как метод лингвистического описания вербальных структур // Вестник Тамбовского университета. Серия: Гуманитарные науки. № 6. C. 229-234.

Орлова О. Г., 2011. Стереотипы-представления о России в американском публицистическом дискурсе // Вопросы когнитивной лингвистики. № 4 (29). С. 93-102.

Орлова О. Г., 2015. Образ России в зарубежных СМИ // Филологические науки. Вопросы теории и практики. № 7-1 (49). С. 146-149.

Осипова А. А., Михина О. В., Позднякова Н. В., 2016. Репрезентация концептов Россия и Германия в публицистических текстах // Вопросы когнитивной лингвистики. № 3 (48). С. 34- 41.

Прохорова К. В., 2012. Заголовочный комплекс в медиатексте: особенности функционирования // Вестник СПбГУ. Язык и литература. № 1. C. $238-246$.

Ребрина Л. Н., Шамне Н. Л., 2017. Репрезентация коллективного прошлого в германских и российских СМИ// Научный диалог. № 11. С. 157-168. DOI: 10.24224/2227-1295-2017-11-157-168.

Точилина Ю. Н., 2013. Особенности вербализации концепта Russland (Россия) в немецких СМИ // Вестник Волгоградского государственного университета. Серия 2, Языкознание. № 1 (17). С. 92-97.

Чурилина Л. Н., 2001. Лексическая структура текста как ключ к реконструкции индивидуальной картины мира // Изменяющийся языковой мир : материалы Междунар. науч. конф. (Пермь, 12-17 нояб. 2001 г.). Пермь : Изд-во Перм. гос. нац. исслед. ун-та. С. 103-105.

Pustejovsky J., 1995. The Generative Lexicon. Cambridge : MIT Press. 312 p.

\section{ИСТОЧНИКИ}

The New York Times. URL: https://www.nytimes.com/ (date of access: 21.06.2020).

The Washington post. URL: https:// www.washingtonpost.com/ (date of access: 21.06.2020).

\section{REFERENCES}

Belousova A.I., 2010. Frejmovaya model kak sposob strukturirovaniya onomasticheskogo koncepta «Rossiya» [Frame model as method of structuring the onomastic concept of Russia] Vestnik Cherepovetskogo gosudarstvennogo universiteta [Cherepovets State University bulletin], no. 3 , pp. 59-63.

Boeva-Omelechko N.B., Posternyak K.P., 2015. Reprezentatsiya assotsiativnoy sostavlyayushchey kontsepta Rossiya v sovremennykh britanskikh SMI [Representation of associative component of the concept Russia in British mass media] Kognitivnye issledovaniya yazyka [Cognitive studies of language], no. 21, pp. 310-312.

In Bin, 2014. Assotsiativno-semanticheskoe pole kontsepta «korova» v sovremennom russkom yazyke [Associative semantic field of concept "cow" in contemporary Russian language]. Izvestiya vysshikh uchebnykh zavedeniy. Seriya "Gumanitarnye nauki» [News of Higher Schools. Series Humanities], no. 4, pp. 311-314. 
Krasilnikova N.A., 2007. «Zalozhniki russkogo medvedya»: metaforicheskoe predstavlenie sovremennoy Rossii v britanskikh i amerikanskikh SMI ["Hostages of the Russian bear": metaphoric concepts of modern Russia in British and American mass media] Voprosy kognitivnoj lingvistiki [Issues of cognitive linguistics], no. (10), pp. 42-49.

Kubryakova E.S., 1996. Kontsept. Kratkiy slovar kognitivnykh terminov, E.S. Kubryakova (ed.) [Concise dictionary of cognitive terms ed. by E.S. Kubryakova]. Moscow, Izdatelstvo Moskovskogo gosudarstvennogo universiteta, pp. 90-92.

Lazareva E.A., 1989. Zagolovokv gazete [Headline in newspapers]. Sverdlovsk, Izdatelstvo Uralskogo universitetata. $96 \mathrm{p}$.

Metody kognitivnogo analiza semantiki slova: kompyuterno-korpusnyy podkhod, 2015. Zabotkina V.I. [i dr.]; pod obshch. red. V.I. Zabotkinoy [Methods of cognitive analyses of word semantics. Zabotkina et. al.,] Moscow, Yazyki slavyanskoy kultury Publ. 344 p.

Nikonova Zh.V. 2007. Frejmovyy analiz kak metod lingvisticheskogo opisaniya verbalnykh struktur [Frame-analysis as a method for describtion of verbal structures]. Vestnik Tambovskogo universiteta. Seriya: Gumanitarnye nauki [Tambov University Review: Series Humanities], no. 6, pp. 229-234.

Orlova O.G., 2011. Stereotipy-predstavleniya o Rossii v amerikanskom publitsisticheskom diskurse [Stereotypes of Russia in American journalistic discourse] Voprosy kognitivnoy lingvistiki [Issues of cognitive linguistics], no. 4 (29), pp. 93-102.

Orlova O.G., 2015. Obraz Rossii v zarubezhnykh SMI [The image of Russia in foreign mass media] Filologicheskie nauki. Voprosy teorii i praktiki [Philology. Theory \& Practice], no 7-1 (49), pp. 146-149. Osipova A.A., Mihina O.V., Pozdnjakova N.V., 2016. Reprezentatsiya kontseptov Rossiya i Germaniya v publitsisticheskikh tekstakh [Representation of concepts Russia and Germany in journalese texts] Voprosy kognitivnoj lingvistiki [Issues of cognitive linguistics], no. 3 (48), pp. 34-41.

Prokhorova K.V., 2012. Zagolovochnyy kompleks v mediatekste: osobennosti funktsionirovaniya [A heading complex of media text: special function] Vestnik SPbGU. Seriya 9. Filologia. Vostokovedenie. Zhurnalistika [Vestnik of Saint Petersburg University. Philology. Oriental Studies. Journalism], no. 1, pp. 238-246.

Rebrina L.N., Shamne N.L., 2017. Reprezentatsiya kollektivnogo proshlogo $\mathrm{v}$ germanskikh i rossiyskikh SMI [Representation of collective past in German and Russian media]. Nauchnyy dialog, no. 11, pp. 157-168. DOI: 10.24224/22271295-2017-11-157-168.

Tochilina Yu.N., 2013. Osobennosti verbalizatsii koncepta Russland (Rossiya) v nemetskikh SMI [Specifics of the verbalization of the concept of Russland (Russia) in German mass media] Vestnik Volgogradskogo gosudarstvennogo universiteta. Serija 2: Yazykoznanie [Science journal of Volgograd State University. Linguistics], no. 1 (17), pp. 92-97.

Churilina L.N., 2001. Leksicheskaya struktura teksta kak klyuch k rekonstruktsii individualnoy kartiny mira [Lexical structure of text as a key to reconstructing individual world picture] Izmenyayushchiysya yazykovoy mir: materialy mezhdunar. nauch. konf. [Changing Language world: conference proceedings]. Perm. Izdatelstvo Permskogo gosudarstvennogo natsionalnogo issledovatelskogo universiteta, pp. 103-105.

Pustejovsky J., 1995. The Generative Lexicon. Cambridge, MIT Press. 312 pp.

\section{SOURCES}

The New York Times. URL: https://www.nytimes.com/ (accessed 21 June 2020).

The Washington post. URL: https:// www.washingtonpost.com/ (accessed 21 June 2020). 


\section{Information About the Authors}

Natalya V. Yudina, Doctor of Sciences (Philology), Director for Monitoring the Activities and Development of Branches, Professor, Department of Foreign Languages and Intercultural Communication, Financial University under the Government of the Russian Federation, Prosp. Leningradskiy, 49, 125993 Moscow, Russia, dr.yudina@mail.ru, https://orcid.org/0000-0002-7305-6959

Oksana A. Seliverstova, Candidate of Sciences (Philology), Associate Professor, Department of Foreign Languages for Professional Communication, Vladimir State University, Gorkogo St, 87, 600000 Vladimir, Russia, oxana33@list.ru, https://orcid.org/0000-0003-2087-0604

\section{Информация об авторах}

Наталья Владимировна Юдина, доктор филологических наук, директор по контролю за деятельностью и развитием филиалов, профессор Департамента иностранных языков и межкультурной коммуникации, Финансовый университет при Правительстве Российской Федерации, просп. Ленинградский, 49, 125993 г. Москва, Россия, dr.yudina@mail.ru, https://orcid.org/0000-0002-7305-6959

Оксана Александровна Селиверстова, кандидат филологических наук, доцент кафедры иностранных языков профессиональной коммуникации, Владимирский государственный университет им. А.Г. и Н.Г. Столетовых, ул. Горького, 87, 600000 г. Владимир, Россия, oxana33@list.ru, https://orcid.org/0000-0003-2087-0604 